\title{
Microstructural Evolution and Properties of Aged Cu-3Ti-3Ni Alloy
}

\author{
Liu Jia ${ }^{1}, \quad$ Wang Xianhui ${ }^{1,2}, \quad$ Guo Tingting $^{2}, \quad$ Zou Juntao ${ }^{1}, \quad$ Yang Xiaohong ${ }^{1}$ \\ ${ }^{1}$ Xi'an University of Technology, Xi'an 710048, China; ${ }^{2}$ Deakin University, Victoria 3220, Australia
}

\begin{abstract}
The effect of aging treatment on the microstructure and the properties of $\mathrm{Cu}-3 \mathrm{Ti}-3 \mathrm{Ni}$ alloy was studied. The microstructure and the precipitated phase were characterized by X-ray diffractometer, scanning electron microscope and transmission electron microscope, and hardness, electrical conductivity and elastic modulus were measured as well. The results show that a number of $\mathrm{Ni}_{3} \mathrm{Ti}$ and $\beta^{\prime}-\mathrm{Cu}_{4} \mathrm{Ti}$ phases precipitate from the $\mathrm{Cu}$ matrix after aging treatment. With the increase of secondary aging time, partial alloying elements dissolve into the $\mathrm{Cu}$ matrix, and the metastable $\mathrm{Cu}_{4} \mathrm{Ti}$ phase transforms into incoherent equilibrium $\mathrm{Cu}_{3} \mathrm{Ti}$ phase. The enhanced electrical conductivity is ascribed to the decrease of Ti solubility in the $\mathrm{Cu}$ matrix by the formation of the $\mathrm{Ni}_{3} \mathrm{Ti}$ and $\beta^{\prime}-\mathrm{Cu}_{4} \mathrm{Ti}$ precipitates. After an appropriate aging treatment of $\mathrm{Cu}-3 \mathrm{Ti}-3 \mathrm{Ni}$ alloy, the $\mathrm{Ni}_{3} \mathrm{Ti}$ and coherent metastable $\beta^{\prime}$ - $\mathrm{Cu}_{4} \mathrm{Ti}$ phases precipitate completely, giving rise to the increase of hardness. Aging treatment has no obvious effect on the elastic modulus of $\mathrm{Cu}-3 \mathrm{Ti}-3 \mathrm{Ni}$ alloy. In the scope of the experiments, the optimal two-step aging treatment parameter for $\mathrm{Cu}-3 \mathrm{Ti}-3 \mathrm{Ni}$ alloy is to age at $300{ }^{\circ} \mathrm{C}$ for $2 \mathrm{~h}$ followed by aging at $450{ }^{\circ} \mathrm{C}$ for $7 \mathrm{~h}$. The $\mathrm{HV}$ hardness, the electrical conductivity and elastic modulus are $1.83 \mathrm{GPa}, 31.34 \%$ IACS (International Annealed Copper Standard) and $148.62 \mathrm{GPa}$, respectively.
\end{abstract}

Key words: copper alloy; aging; phase transformation; precipitation

Age-hardened $\mathrm{Cu}$-based alloys are indispensable for the electrical connection, high strength springs, electrical contacts, and corrosion and wear resistant materials ${ }^{[1-3]}$, and among them, the $\mathrm{Cu}-\mathrm{Be}$ alloys exhibit a good combination of electrical conductivity and mechanical properties. However, the anti-stress relaxation property of $\mathrm{Cu}-\mathrm{Be}$ alloys is poor as used at elevated temperatures ${ }^{[4]}$. Moreover, $\mathrm{Cu}-\mathrm{Be}$ alloys are highly sensitive to heat treatment process, giving rise to unstable performances. Furthermore, their toxicity brings about the environmental and health hazards as well. Subsequently, it is of great significance to develop a substituent for $\mathrm{Cu}-\mathrm{Be}$ alloys. Since $\mathrm{Cu}-\mathrm{Ti}$ alloys have high strength, hardness and elasticity, good wear resistance, corrosion resistance, workability and weldability as well as high-temperature performance, they have potential as substitutes for $\mathrm{Cu}-\mathrm{Be}$ alloys. So far, numerous researches on the strengthening mechanism of $\mathrm{Cu}-\mathrm{Ti}$ alloys have revealed that age hardening takes place by introducing finely dispersed $\mathrm{Cu}_{4} \mathrm{Ti}$ particles through heat treatments, but overaging causes the phase transformation from metastable $\beta^{\prime}-\mathrm{Cu}_{4} \mathrm{Ti}$ to incoherent equilibrium $\mathrm{Cu}_{3} \mathrm{Ti}$ phase, significantly decreasing the strength of $\mathrm{Cu}-\mathrm{Ti}$ alloys ${ }^{[2,5-8]}$. In comparison with $\mathrm{Cu}-\mathrm{Be}$ alloys, $\mathrm{Cu}-\mathrm{Ti}$ alloys have lower electrical conductivity due to the much larger contribution of solute $\mathrm{Ti}$ atoms to the electrical resistivity compared to $\mathrm{Be}$ atoms ${ }^{[9-11]}$. It is desired to improve the electrical conductivity of $\mathrm{Cu}$-Ti alloys without deteriorating mechanical strength. Therefore, some attempts have been made to improve the electrical conductivity of binary $\mathrm{Cu}$-Ti alloys by reducing solute $\mathrm{Ti}$ atoms in the copper matrix ${ }^{[12-14]}$. Konno et al. ${ }^{[12]}$ reported that the electrical conductivity of $\mathrm{Cu}-3$ at\% Ti alloy with 4 at\% $\mathrm{Al}$ addition is 6 times larger than that without $\mathrm{Al}$ addition, whereas the peak

Received date: October 21, 2015

Foundation item: National Natural Science Foundation of China (51201132); Shaanxi Provincial Key Laboratory Research Program (13JS076); Shaanxi Provincial Project of Special Foundation of Key Disciplines (2011HBSZS009); The Pivot Innovation Team of Shaanxi Electrical Materials and Infiltration Technique (2012KCT-25).

Corresponding author: Wang Xianhui, Ph. D., Professor, School of Materials Science and Engineering, Xi'an University of Technology, Xi'an 710048, P. R. China, Tel: 0086-29-82312185, E-mail: xhwang693@xaut.edu.cn

Copyright $($ C 2016, Northwest Institute for Nonferrous Metal Research. Published by Elsevier BV. All rights reserved. 
HV hardness decreases from 2.80 GPa to $1.80 \mathrm{GPa}$. Semboshi et al. ${ }^{[13]}$ revealed that the electrical conductivity of $\mathrm{Cu}-1$ at $\% \mathrm{Ti}$ alloy by aging in a hydrogen $\left(\mathrm{H}_{2}\right)$ atmosphere increased by $140 \%$ compared to that of the same alloy aged in a vacuum. The high electrical conductivity is attributed to the formation of $\mathrm{TiH}_{2}$, which can efficiently remove the Ti solutes from the $\mathrm{Cu}$ matrix. However, the hardness of $\mathrm{Cu}-1$ at\% Ti alloy drops more rapidly upon aging in the hydrogen atmosphere in comparison to the vacuum aging treatment due to the formation of the brittle $\mathrm{TiH}_{2}$ phase. Markandeya et al. ${ }^{[14]}$ reported that $\mathrm{Cd}$ addition decreases the electrical conductivity of $\mathrm{Cu}-3 \mathrm{Ti}$ alloy though the yield strength and tensile strength increase considerably.

Generally, copper base alloys with good comprehensive properties are solution treated by quenching and subsequent ageing. A number of nano-sized precipitates can be formed in copper matrix through these processes; as a result that the alloy is strengthened and its electrical conductivity is increased. As $\mathrm{Ni}$ has a strong affinity with $\mathrm{Ti}$ to form $\mathrm{Ni}_{3} \mathrm{Ti}$ intermetallic compound which has high melting point, it has a large tendency to push $\mathrm{Ti}$ atoms out of copper matrix, decreasing the solid solubility of $\mathrm{Ti}$ in the $\mathrm{Cu}$ matrix, and thus, it is favorable for the improvement of the properties of $\mathrm{Cu}-\mathrm{Ti}$ alloys. So far, no literatures have been reported on the effect of $\mathrm{Ni}$ addition on the mechanical properties and the microstructure of $\mathrm{Cu}$-Ti alloy. In the present work, the effects of $\mathrm{Ni}$ addition and heat treatment on the microstructure and the properties of $\mathrm{Cu}-3 \mathrm{Ti}$ alloy were studied. The microstructure and the phase constituents were characterized by X-ray diffractometer (XRD), scanning electron microscope (SEM) and transmission electron microscope (TEM), and the electrical conductivity, the hardness and the elastic modulus were measured as well. The purpose of the present study is to examine the effect of $\mathrm{Ni}$ addition on the electrical and mechanical properties of $\mathrm{Cu}-3 \mathrm{Ti}$ alloy, and to shed a light on the aging behavior of $\mathrm{Cu}-3 \mathrm{Ti}-3 \mathrm{Ni}$ alloy and phase transformation by structural characterization using TEM.

\section{Experiment}

Button ingots of $\mathrm{Cu}-3 \mathrm{Ti}-3 \mathrm{Ni}$ alloy were prepared from purity $99.9 \mathrm{wt} \%$ electrolytic copper, purity $99.9 \mathrm{wt} \%$ titanium and purity 99.9 wt\% nickel by arc-melting in an argon atmosphere. Each ingot was melted at least four times to guarantee its homogeneity. The ingots were cut into blocks, and then solution treated at $850{ }^{\circ} \mathrm{C}$ for $4 \mathrm{~h}$ in a SK-G10123K tube furnace, followed by water quenching. Immediately after quenching, the samples were aged at $300{ }^{\circ} \mathrm{C}$ for $2 \mathrm{~h}$, followed by aging at $450{ }^{\circ} \mathrm{C}$ for $1,3,5,7$ and $11 \mathrm{~h}$ in an argon atmosphere (two-step aging). After mechanical polishing, the samples were etched in a solution of $5 \mathrm{~g} \mathrm{FeCl}_{3}, 15 \mathrm{~mL} \mathrm{HCl}$ and $100 \mathrm{~mL}$ distilled water. The phase constituents were determined by a D8ADVANCE X-ray diffractometer operating at $40 \mathrm{kV}$ and $40 \mathrm{~mA}, \mathrm{Cu}-\mathrm{K} \alpha$ radiation, $\lambda=0.15406 \mathrm{~nm}$, and microstructure was examined by a JEOL JSM-6700F field emission scanning electron microscope (SEM). The specimens used for TEM observation were cut from the block using an IsoMet 1000 cutting machine and then mechanically polished to obtain $50 \mu \mathrm{m}$ thick slices. Discs with $3 \mathrm{~mm}$ diameter were punched out of these slices and thinned in a M691 ion milling at $4.5 \mathrm{kV}$. TEM studies were carried out using a JEM-2100HR high resolution transmission electron microscope (HRTEM) with operation voltage of $200 \mathrm{kV}$. The electrical conductivity was tested in a FQR-7501 eddy conductivity gauge. Hardness measurements were carried out using a HV-1000 Vickers hardness tester under an applied load of $98 \mathrm{~N}$ and a holding time of $10 \mathrm{~s}$. The average hardness was obtained from five indentations. The elastic modulus was determined by a G200 Agilent nano indenter, and its value was the average of five measurements.

\section{Results and Discussion}

\subsection{Microstructural characterization}

$\mathrm{X}$-ray diffraction analysis was performed to detect phase constituents of as-cast $\mathrm{Cu}-3 \mathrm{Ti}-3 \mathrm{Ni}$ alloy, and the XRD pattern is shown in Fig.1. According to the $\mathrm{X}$-ray diffraction analysis, as-cast $\mathrm{Cu}-3 \mathrm{Ti}-3 \mathrm{Ni}$ alloy consists of NiTi phase and $\mathrm{Cu}$ matrix. Fig. 2 is the microstructure of as-cast $\mathrm{Cu}-3 \mathrm{Ti}-3 \mathrm{Ni}$ alloy. It can be seen that NiTi phase is uniformly distributed in the $\mathrm{Cu}$ matrix.

Fig.3a Fig.3e show the microstructures of $\mathrm{Cu}-3 \mathrm{Ti}-3 \mathrm{Ni}$ alloy after various aging treatments. As seen from Fig.3a, the

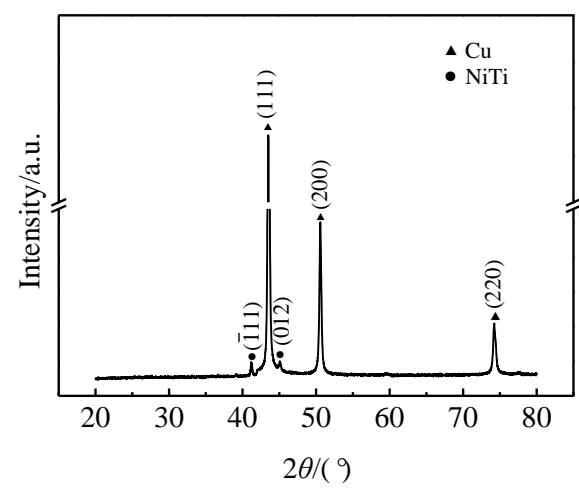

Fig.1 XRD pattern of as-cast $\mathrm{Cu}-3 \mathrm{Ti}-3 \mathrm{Ni}$ alloy

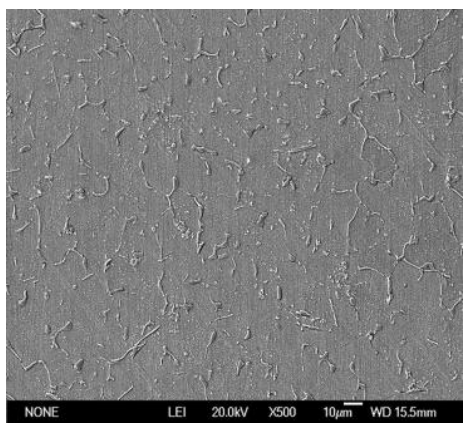

Fig.2 Microstructure of as-cast $\mathrm{Cu}-3 \mathrm{Ti}-3 \mathrm{Ni}$ alloy 


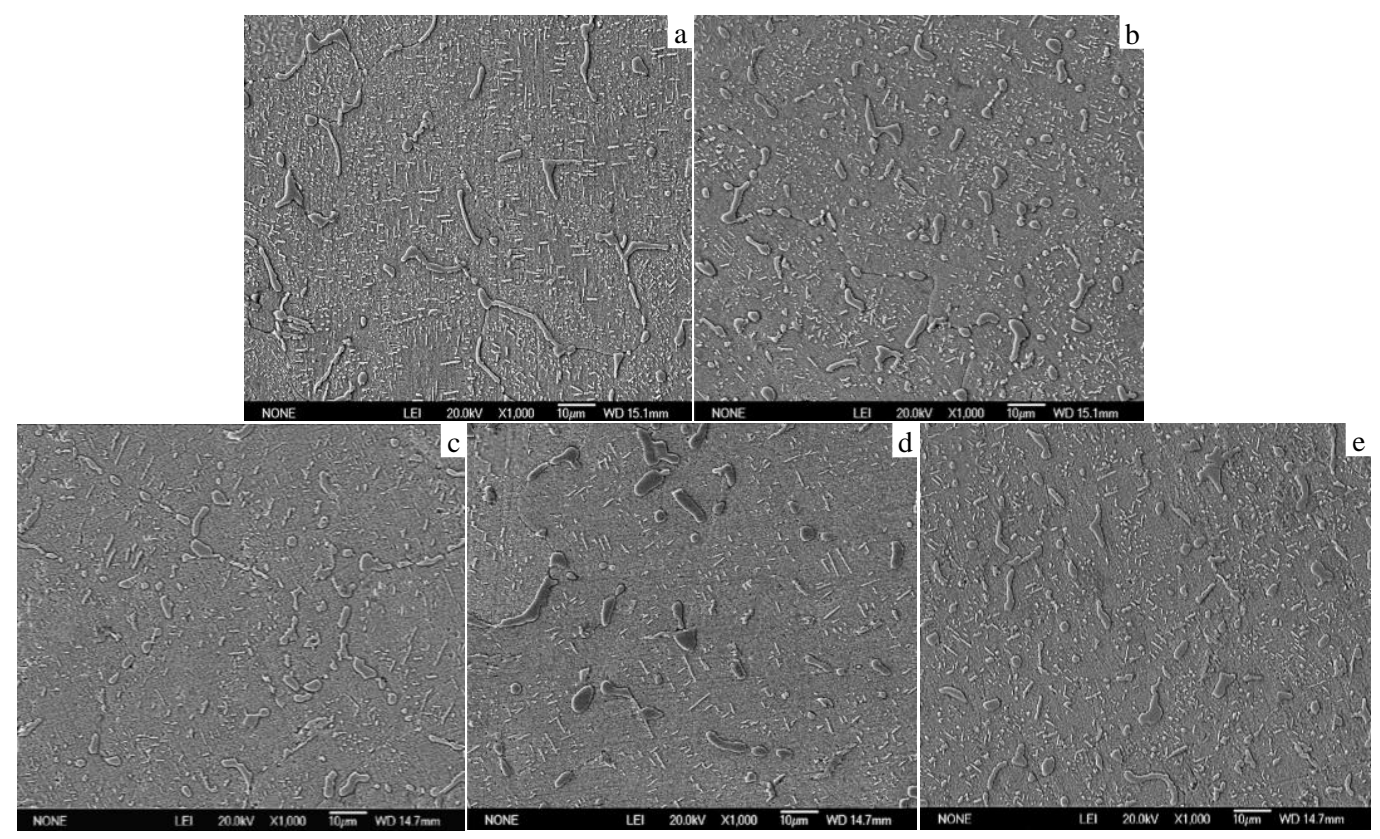

Fig.3 SEM images of Cu-3Ti-3Ni alloy aged at $300^{\circ} \mathrm{C}$ for $2 \mathrm{~h}$ and $450{ }^{\circ} \mathrm{C}$ for different time: (a) $1 \mathrm{~h}$, (b) $3 \mathrm{~h}$, (c) $5 \mathrm{~h}$, (d) $7 \mathrm{~h}$, and (e) $11 \mathrm{~h}$

secondary phase presents platelet-like and spherical shape after two-step aging at $300{ }^{\circ} \mathrm{C}$ for $2 \mathrm{~h}$ and $450{ }^{\circ} \mathrm{C}$ for $1 \mathrm{~h}$. After two-step aging at $300{ }^{\circ} \mathrm{C}$ for $2 \mathrm{~h}$ and $450{ }^{\circ} \mathrm{C}$ for $3 \mathrm{~h}$, the amount of spherical phase decreases, as shown Fig.3b. As seen from Fig.3c, the amount of the spherical phase decreases sharply after two-step aging at $300{ }^{\circ} \mathrm{C}$ for $2 \mathrm{~h}$ and $450{ }^{\circ} \mathrm{C}$ for 5 h. After two-step aging at $300{ }^{\circ} \mathrm{C}$ for $2 \mathrm{~h}$ and $450{ }^{\circ} \mathrm{C}$ for $7 \mathrm{~h}$, the spherical phases disappear and the platelet-like phases are distributed uniformly in the $\mathrm{Cu}$ matrix (Fig.3d). However, prolonged aging gives rise to the partial dissolution of alloying elements into the $\mathrm{Cu}$ matrix and thus some spherical phases increase, as seen in Fig.3e. Fig.4 is an enlarged view of Fig.3e, where the continuous platelet-like phase become discontinuous. In addition, some continuous NiTi phase becomes discontinuous completely.

\subsection{TEM observation}

In order to determine the precipitated phases of the aged $\mathrm{Cu}-3 \mathrm{Ti}-3 \mathrm{Ni}$ alloy, two specimens after two-step aging at 300

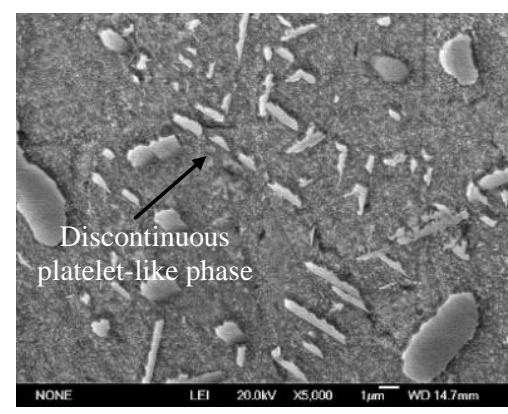

Fig.4 SEM image of $\mathrm{Cu}-3 \mathrm{Ti}-3 \mathrm{Ni}$ alloy aged at $300{ }^{\circ} \mathrm{C}$ for $2 \mathrm{~h}$ and $450{ }^{\circ} \mathrm{C}$ for $11 \mathrm{~h}$ (enlarged view of Fig.3e)
${ }^{\circ} \mathrm{C}$ for $2 \mathrm{~h}$ and $450{ }^{\circ} \mathrm{C}$ for $7 \mathrm{~h}$, and $300{ }^{\circ} \mathrm{C}$ for $2 \mathrm{~h}$ and $450{ }^{\circ} \mathrm{C}$ for $11 \mathrm{~h}$ were characterized by TEM.

Fig.5a is a low-magnification bright-field BF TEM image of the $\mathrm{Cu}-3 \mathrm{Ti}-3 \mathrm{Ni}$ alloy aged at $300{ }^{\circ} \mathrm{C}$ for $2 \mathrm{~h}$ and $450{ }^{\circ} \mathrm{C}$ for $7 \mathrm{~h}$. As indicated by black arrows in Fig.5a, the platelet-like phase is $1.5 \mu \mathrm{m}$ in length and $200 \mathrm{~nm}$ in width. Fig. $5 \mathrm{~b} \sim$ Fig. $5 \mathrm{~d}$ are a high-magnification bright field image (BF), a selected area diffraction (SAD) pattern and its schematic diagram, respectively. As demonstrated from Fig.5c and Fig.5d, the tiny precipitated phase is $\mathrm{Ni}_{3} \mathrm{Ti}$ with a hexagonal structure of structure parameters: $a=0.5092 \mathrm{~nm}, b=0.5092 \mathrm{~nm}, c=0.8297$ nm.

Fig.6a is the low-magnification BF image of the same specimen. Apart from the $\mathrm{Ni}_{3} \mathrm{Ti}$ precipitates, it is noticed that there are continuous fine precipitates with a length of approximate $100 \mathrm{~nm}$. The corresponding SAD pattern and its schematic diagram are shown in Fig.6b and Fig.6c, respectively. It can be identified that the ordered, metastable and coherent $\beta^{\prime}-\mathrm{Cu}_{4} \mathrm{Ti}$ precipitate has formed with an orthorhombic structure of structure parameters: $a=0.4530 \mathrm{~nm}$, $b=0.4342 \mathrm{~nm}, c=1.2930 \mathrm{~nm}$.

Fig.7 is the TEM images of $\mathrm{Cu}-3 \mathrm{Ti}-3 \mathrm{Ni}$ alloy aged at $300{ }^{\circ} \mathrm{C}$ for $2 \mathrm{~h}$ and $450{ }^{\circ} \mathrm{C}$ for $11 \mathrm{~h}$. Obviously, Fig.7a shows another tiny precipitated phase distributed in the $\mathrm{Cu}$ matrix for the same specimen. Fig.7b and Fig.7c are a corresponding SAD pattern and its schematic diagram, respectively. The analysis of SAD pattern indicates that the incoherent fine precipitated phase is $\mathrm{Cu}_{3} \mathrm{Ti}$ having an orthorhombic structure with structure parameters: $a=0.545 \mathrm{~nm}, b=0.442 \mathrm{~nm}, c=$ $0.430 \mathrm{~nm}$ as indicated by the black arrow in Fig.7a. It suggests that prolonged aging promotes the phase transformation 


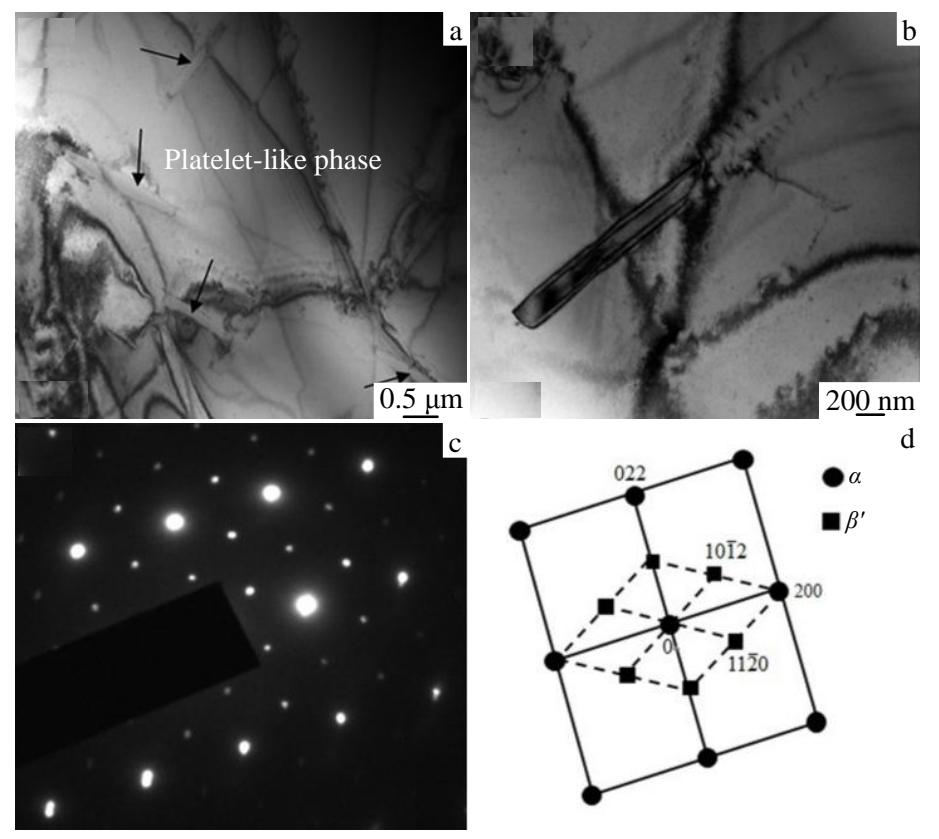

Fig.5 TEM images of $\mathrm{Cu}-3 \mathrm{Ti}-3 \mathrm{Ni}$ alloy aged at $300{ }^{\circ} \mathrm{C}$ for $2 \mathrm{~h}$ and $450{ }^{\circ} \mathrm{C}$ for $7 \mathrm{~h}$ : (a) low magnification image, (b) BF-TEM image, (c) SAD pattern, and (d) schematic diagram

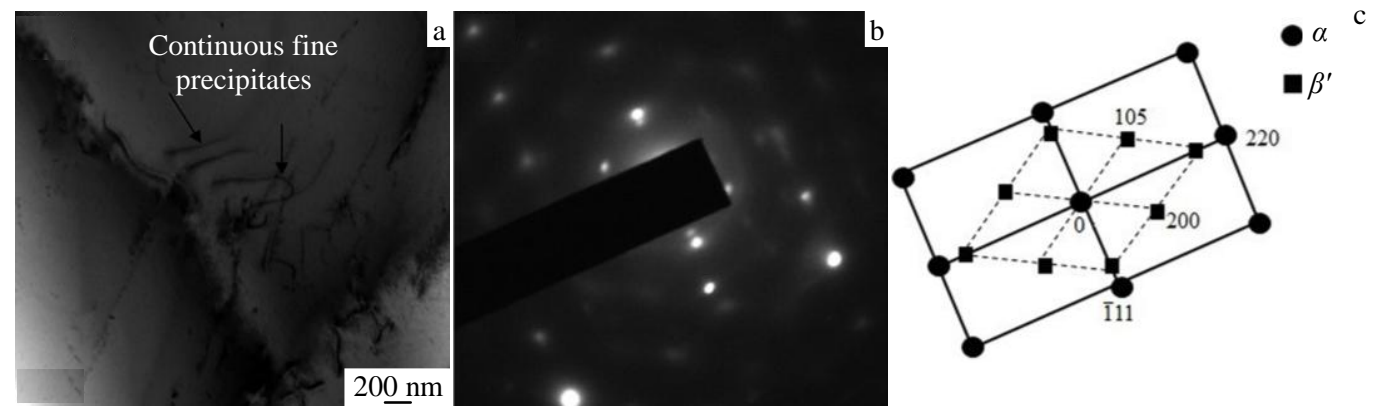

Fig.6 TEM images of $\mathrm{Cu}-3 \mathrm{Ti}-3 \mathrm{Ni}$ alloy aged at $300{ }^{\circ} \mathrm{C}$ for $2 \mathrm{~h}$ and $450{ }^{\circ} \mathrm{C}$ for $7 \mathrm{~h}$ : (a) low magnification image, (b) SAD pattern, and (c) schematic diagram
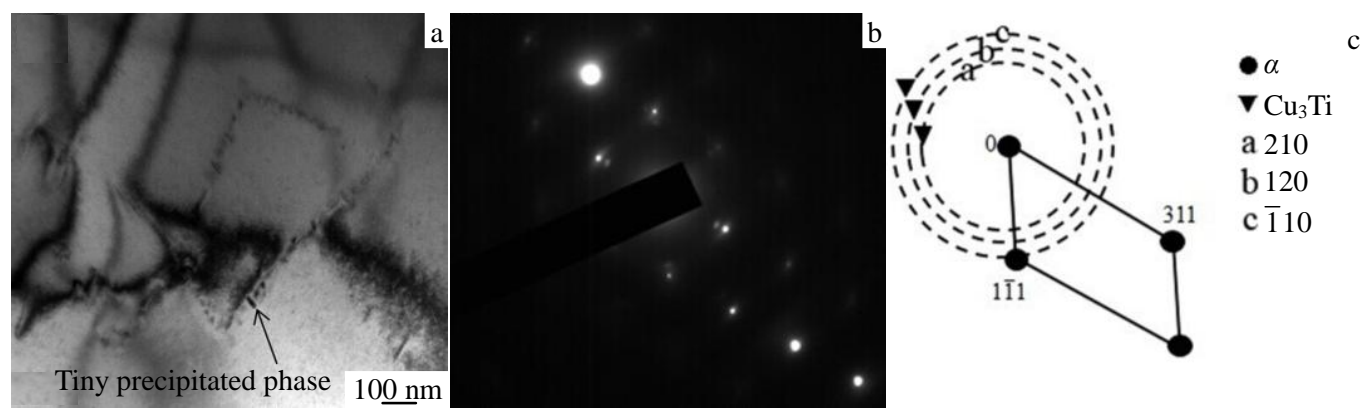

Fig.7 TEM images of $\mathrm{Cu}-3 \mathrm{Ti}-3 \mathrm{Ni}$ alloy aged at $300{ }^{\circ} \mathrm{C}$ for $2 \mathrm{~h}$ and $450{ }^{\circ} \mathrm{C}$ for $11 \mathrm{~h}$ : (a) low magnification image, (b) SAD pattern, and (c) schematic diagram

from $\mathrm{Cu}_{4} \mathrm{Ti}$ phase to $\mathrm{Cu}_{3} \mathrm{Ti}$ one. This finding is in good accordance with the result reported by Markandeya et al. ${ }^{[15]}$.

2.3 Hardness and electrical conductivity of $\mathrm{Cu}-3 \mathrm{Ti}-3 \mathrm{Ni}$ alloy
Fig. 8 shows the variation of hardness and electrical conductivity with secondary aging time for $\mathrm{Cu}-3 \mathrm{Ti}-3 \mathrm{Ni}$ alloy. It is evident that the hardness increases and then slightly decreases with the increase of secondary aging time. At $7 \mathrm{~h}$, 


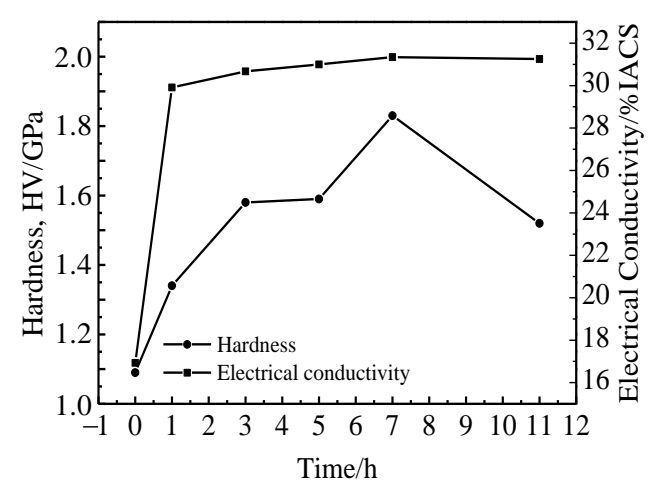

Fig.8 Variation of hardness and electrical conductivity with secondary aging time for $\mathrm{Cu}-3 \mathrm{Ti}-3 \mathrm{Ni}$ alloy

Cu-3Ti-3Ni alloy reaches its peak HV hardness of $1.83 \mathrm{GPa}$. This change is closely related to the formation of precipitated phases. At the early stage of aging, the secondary $\mathrm{Ni}_{3} \mathrm{Ti}$ and $\beta^{\prime}-\mathrm{Cu}_{4} \mathrm{Ti}$ phase continuously precipitate from supersaturated $\mathrm{Cu}$ matrix. Moreover, $\beta^{\prime}-\mathrm{Cu}_{4} \mathrm{Ti}$ phase is coherent with the $\mathrm{Cu}$ matrix $^{[15]}$. Thus, the hardness increases progressively till it reaches the peak value. However, further aging gives rise to the partial dissolution of alloying elements into the $\mathrm{Cu}$ matrix (see Fig.3e), and the phase transformation from $\beta^{\prime}-\mathrm{Cu}_{4} \mathrm{Ti}$ to incoherent equilibrium $\mathrm{Cu}_{3} \mathrm{Ti}$ (see Fig.7), thus reducing the hardness after aging for above $7 \mathrm{~h}$.

As shown in Fig.8, the electrical conductivity of $\mathrm{Cu}-3 \mathrm{Ti}-3 \mathrm{Ni}$ alloy rises sharply after two-step aging at $300{ }^{\circ} \mathrm{C}$ for $2 \mathrm{~h}$ and $450{ }^{\circ} \mathrm{C}$ for $1 \mathrm{~h}$, and then increases slightly with prolonging of secondary aging time. The electrical conductivity can reach up to $31.34 \%$ IACS after aging at $300{ }^{\circ} \mathrm{C}$ for 2 $\mathrm{h}$ and $450{ }^{\circ} \mathrm{C}$ for $7 \mathrm{~h}$. However, there is a slight decrease in the electrical conductivity if secondary aging time is above $7 \mathrm{~h}$. After secondary aging at $450{ }^{\circ} \mathrm{C}$ for $11 \mathrm{~h}$, the electrical conductivity of $\mathrm{Cu}-3 \mathrm{Ti}-3 \mathrm{Ni}$ alloy decreases by $0.29 \%$ compared with that of the alloy aged at $450{ }^{\circ} \mathrm{C}$ for $7 \mathrm{~h}$. This can be explained as follows. Though electrical conductivity is sensitive to a number of microstructural factors including vacancy concentration, solute concentration in the matrix, precipitate size and precipitate volume fraction, the electrical conductivity primarily depends on the solubility of alloying elements in the $\mathrm{Cu}$ matrix ${ }^{[16-18]}$. At the initial stage of secondary aging, $\mathrm{Ti}$ and $\mathrm{Ni}$ have large supersaturated concentrations in the $\mathrm{Cu}$ matrix, so there exist large precipitation kinetics and formation rates of precipitates. Eventually, these solute atoms in the $\mathrm{Cu}$ matrix will be greatly reduced by the precipitation of the second phases during aging, which decrease lattice distortion and electron scattering remarkably, increase the electrical conductivity sharply. However, the contents of $\mathrm{Ti}$ and $\mathrm{Ni}$ elements in the $\mathrm{Cu}$ matrix reduce progressively with further aging, and the amount of precipitates decrease correspondingly. Hence, no obvious change occurs for the electrical conductivity. The tiny
Table 1 Elastic moduli of $\mathrm{Cu}-3 \mathrm{Ti}-3 \mathrm{Ni}$ alloy after various aging treatments

\begin{tabular}{ccc}
\hline Aging treatment & $\begin{array}{c}\text { Elastic modulus/ } \\
\text { GPa }\end{array}$ & Standard deviation \\
\hline $300{ }^{\circ} \mathrm{C}$ for $2 \mathrm{~h} / 4500^{\circ} \mathrm{C}$ for $1 \mathrm{~h}$ & 147.76 & 3.34 \\
$300^{\circ} \mathrm{C}$ for $2 \mathrm{~h} / 4500^{\circ} \mathrm{C}$ for $3 \mathrm{~h}$ & 147.95 & 1.89 \\
$300{ }^{\circ} \mathrm{C}$ for $2 \mathrm{~h} / 450{ }^{\circ} \mathrm{C}$ for $5 \mathrm{~h}$ & 148.65 & 3.19 \\
$300{ }^{\circ} \mathrm{C}$ for $2 \mathrm{~h} / 4500^{\circ} \mathrm{C}$ for $7 \mathrm{~h}$ & 148.62 & 1.56 \\
$300{ }^{\circ} \mathrm{C}$ for $2 \mathrm{~h} / 450{ }^{\circ} \mathrm{C}$ for $11 \mathrm{~h}$ & 150.04 & 4.35 \\
\hline
\end{tabular}

fluctuation for secondary aging at $450{ }^{\circ} \mathrm{C}$ for $11 \mathrm{~h}$ is probably due to the partial dissolution of alloying elements into the $\mathrm{Cu}$ matrix after longer aging time.

\subsection{Elastic modulus of $\mathrm{Cu}-3 \mathrm{Ti}-3 \mathrm{Ni}$ alloy}

The elastic moduli of $\mathrm{Cu}-3 \mathrm{Ti}-3 \mathrm{Ni}$ alloy after two-step aging at $300{ }^{\circ} \mathrm{C}$ for $2 \mathrm{~h}$ and $450{ }^{\circ} \mathrm{C}$ for $1,3,5,7$ and $11 \mathrm{~h}$ are listed in Table 1. It is seen that the elastic modulus of $\mathrm{Cu}-3 \mathrm{Ti}-3 \mathrm{Ni}$ alloy after various aging treatments almost keeps constant in the range of the error. It is indicated that aging treatment has no remarkable effect on the elastic modulus of $\mathrm{Cu}-3 \mathrm{Ti}-3 \mathrm{Ni}$ alloy. This is in good agreement with the conventional viewpoint $^{[19,20]}$. Generally, it is believed that the elastic modulus of the metallic materials is insensitive to microstructure, alloying elements, heat treatment and cold deformation.

\section{Conclusions}

1) $\mathrm{Ni}$ addition reduces the solute $\mathrm{Ti}$ content in the copper matrix, increasing the electrical conductivity.

2) An appropriate aging promotes the precipitation of $\mathrm{Ni}_{3} \mathrm{Ti}$ and $\beta^{\prime}-\mathrm{Cu}_{4} \mathrm{Ti}$ phase, which are beneficial for improving both the electrical conductivity and hardness.

3) Prolonged aging brings about the partial dissolution of alloying elements into the $\mathrm{Cu}$ matrix and phase transformation from the metastable $\mathrm{Cu}_{4} \mathrm{Ti}$ phase to incoherent equilibrium $\mathrm{Cu}_{3} \mathrm{Ti}$ phase, resulting in the decrease of hardness.

4) Aging treatment has no remarkable effect on the elastic modulus of $\mathrm{Cu}-3 \mathrm{Ti}-3 \mathrm{Ni}$ alloy.

5) In the scope of experiments, $\mathrm{Cu}-3 \mathrm{Ti}-3 \mathrm{Ni}$ alloy has good combined properties after two-step aging treatment at $300{ }^{\circ} \mathrm{C}$ for $2 \mathrm{~h}$ and $450{ }^{\circ} \mathrm{C}$ for $7 \mathrm{~h}$. The $\mathrm{HV}$ hardness, the electrical conductivity and the elastic modulus reach $1.83 \mathrm{GPa}$, $31.34 \% \mathrm{IACS}$ and $148.62 \mathrm{GPa}$, respectively.

\section{References}

1 Soffa W A, Laughlin D E. Progress in Materials Science[J], 2004, 49: 347

2 Nagarjuna S, Srinivas M, Balasubramanian K et al. Materials Science and Engineering A[J], 1999, 256: 34

3 Borchers C. Philosophical Magazine[J], 1999, 79: 537

4 Liu P, Ren F Z, Jia S G. Copper Alloys and Applications[M]. Beijing: Chemical Industry Press, 2007: 110 (in Chinese)

5 Nagarjuna S, Balasubramanian K, Sarma D S. Materials 
Transactions, JIM[J], 1995, 36: 1058

6 Božića D, Dimčićb O, Dimčića B et al. Materials Characterization[J], 2008, 59: 1122

7 Nagarjuna S, Babu U C, Ghosal P. Materials Science and Engineering A[J], 2008, 491: 331

8 Markandeya R, Nagarjuna S, Sarma D S. Materials Characterization[J], 2005, 54: 360

9 Nagarjuna S, Balasubramanian K, Sarma D S. Materials Science and Engineering $A[\mathrm{~J}], 1997,225: 118$

10 Suzuki S, Hirabayashi K, Shibata H et al. Scripta Materialia[J], 2003, 48: 431

11 Semboshi S, Konno T J. Journal of Materials Research[J], 2008, 23: 473

12 Konno T J, Nishio R, Semboshi S. Journal of Materials Science $[\mathrm{J}], 2008,43: 3761$
13 Semboshi S, Al-Kassab T, Gemma R et al. Ultramicroscopy[J], 2009, 109: 593

14 Markandeya R, Nagarjuna S, Sarma D S. Journal of Materials Engineering and Performance[J], 2007, 16: 640

15 Markandeya R, Nagarjuna S, Satyanarayana D V V et al. Materials Science and Engineering A[J], 2006, 428: 233

16 Feng Y, Wang R C, Peng C Q. Intermetallics[J], 2013, 33: 120

17 Guo F A, Xiang C J, Yang C X et al. Materials Science and Engineering $B[\mathrm{~J}], 2008,147: 1$

18 Raeisiula B, Poole W J. Materials Science Forum[J], 2006, 519-521: 1391

19 Fujiwara K, Tanimoto H, Mizubayashi H. Materials Science and Engineering $A[\mathrm{~J}], 2006,442: 336$

20 Kikuchi M, Takahashi M, Okuno O. Dental Materials Journal[J], 2006, 22: 64

\title{
时效处理对 Cu-3Ti-3Ni 合金组织与性能的影响
}

\author{
刘 佳 $^{1}$, 王献辉 ${ }^{1,2}$, 郭婷婷 ${ }^{2}$, 邹军涛 ${ }^{1}$, 杨晓红 ${ }^{1}$ \\ (1. 西安理工大学, 陕西 西安 710048) \\ (2. 迪肯大学, 澳大利亚 VIC 3220)
}

\begin{abstract}
摘 要: 研究了时效处理对 $\mathrm{Cu}-3 \mathrm{Ti}-3 \mathrm{Ni}$ 合金组织与性能的影响。采用 $\mathrm{X}$ 射线衍射仪(XRD)、扫描电子显微镜(SEM)及透射电子显微镜(TEM) 对 Cu-3Ti-3Ni 合金的组织和析出相进行了表征，并对其硬度、导电率和弹性模量进行了测试。结果表明: Cu-3Ti-3Ni 合金时效处理后析 出 $\mathrm{Ni}_{3} \mathrm{Ti}$ 及 $\beta^{\prime}-\mathrm{Cu}_{4} \mathrm{Ti}$ 相。随着时效时间的延长, 部分合金元素回溶于 $\mathrm{Cu}$ 基体, 连续的亚稳定 $\beta^{\prime}-\mathrm{Cu}_{4} \mathrm{Ti}$ 相向不连续的稳定 $\mathrm{Cu}_{3} \mathrm{Ti}$ 相转变。

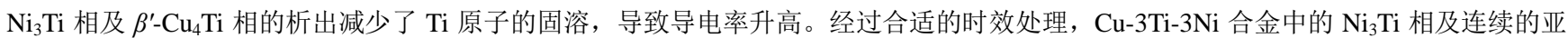
稳定 $\beta^{\prime}-\mathrm{Cu}_{4} \mathrm{Ti}$ 相析出完全, 导致硬度升高, 但时效处理对合金弹性模量影响不大。在本实验范围内, $\mathrm{Cu}-3 \mathrm{Ti}-3 \mathrm{Ni}$ 合金的最佳时效处理工 艺是 $300{ }^{\circ} \mathrm{C}$ 时效 $2 \mathrm{~h}$ 后炉冷, 随后 $450{ }^{\circ} \mathrm{C}$ 时效 $7 \mathrm{~h}$ 炉冷。Cu-3Ti-3 Ni 合金的 HV 硬度、导电率及弹性模量分别是 $1.83 \mathrm{GPa} 、 31.34 \% \mathrm{IACS}$ (国际退火铜标准)及 $148.62 \mathrm{GPa}$ 。
\end{abstract}

关键词：铜合金; 时效; 相变; 析出相

作者简介: 刘 佳, 女, 1987 年生, 博士生, 西安理工大学材料科学与工程学院, 陕西 西安 710048, 电话: 029-82312185, E-mail: liujia9200920@163.com 